

\section{RECODE - Responding to Complex Diversity in Europe and Canada}

\section{ONLINE WORKING PAPER SERIES}

RECODE, a research networking programme financed through the European Science Foundation (ESF), is intended to explore to what extent the processes of transnationalisation, migration, religious mobilisation and cultural differentiation entail a new configuration of social conflict in post-industrial societies - a possible new constellation labelled complex diversity.

RECODE brings together scholars from across Europe and Canada in a series of scientific activities. More information about the programme and the working papers series is available via the RECODE websites:

www.recode.fi

www.recode.info

www.esf.org/recode

Series Editor: Peter A. Kraus

Section 3, Workshop 5:

Multireligious Society: Accommodating New Religious Diversities in Post-Secular Settings

Title: Translocal, Faith-based Dispute Management: Moroccan-Canadian Struggles with Normative Plurality

Author: Bertram Turner

Working Paper No. 27

Publication Date of this Version: January 2014

Webpage: http://www.recode.info

(c) RECODE, 2014

Augsburg, Germany

http://www.recode.info

(C) 2014 by Bertram Turner

All rights reserved.

Short sections of text, not to exceed

two paragraphs, may be quoted without

explicit permission provided that full credit

is given to the source.

The views expressed in this paper do not necessarily reflect those of the RECODE Research Networking Programme or the European Science Foundation.

Bertram Turner

Max Planck Institute for Social Anthropology

turner@eth.mpg.de

ISSN 2242-3559

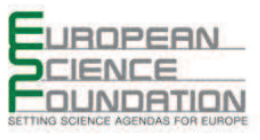

Standing Committee for the Social Sciences (SCSS)

Standing Committee for the Humanities $(\mathrm{SCH})$ 


\title{
Translocal, Faith-based Dispute Management: Moroccan- Canadian Struggles with Normative Plurality
}

\begin{abstract}
Bertram Turner
Bertram Turner is a senior researcher at the Max Planck Institute for Social Anthropology, in the Department of Law \& Anthropology, Halle/Saale, Germany. Before joining the Max Planck Institute for Social Anthropology, he was assistant professor at the Institute of Social Anthropology and African Studies in Munich between 1993 and 2001. He received his doctorate for comparative research on asylum and conflict in 1996. He has conducted extended field research in the Middle East and North Africa, Germany and Canada. His research in Canada has a specific focus on faith-based dispute management and on processes of translation within the nomosphere, especially between Moroccans and Canadians of Moroccan origin. He has published widely on the anthropology of law, religion, conflict, morality, development, and resource extraction.
\end{abstract}

\section{Abstract}

The Multiculturalism Act in the Canadian Constitution is regarded as one of the most advanced and path-breaking state legislations worldwide concerning the recognition of cultural diversity. However, there is a countrywide debate in Canada on the extent to which informal normative repertoires, 'cultural normativity', belief systems, and religious law are to be considered part of the cultural inventory to be recognized. Focusing on a concrete case, the paper combines different analytical strands connected to the Canadian discourse and analyzes the way in which the provision of normative agency for self-regulation within religious communities has been challenged over the last decade, particularly for Canadian Muslims.

With the passage of the Canadian Multiculturalism Act of 1988, one of the most advanced and path-breaking state legislations worldwide (e.g. Tierney 2007), core elements of the Multiculturalism Policy of 1971 and earlier legislations aiming to preserve and enhance multiculturalism in Canada were absorbed into the Canadian Charter of Rights and Freedoms. Freedom of religion is expressly recognized in the Charter as a fundamental freedom through which protection to religious minorities is guaranteed. Against that backdrop, a controversial debate has ensued countrywide concerning the scope of legal entitlements, in particular on the question of whether informal normative repertoires, 'cultural normativity,' belief systems, and religious law were considered part and parcel of cultural diversity (Moon 2008). The questions that most resonate within this debate have to do with the risks implied in permitting internal dispute regulation within religious communities. The issue here is the extent and the conditions under which such normative registers offer a valid framework for the regulation of intracommunitarian disputes under state law. Is it possible to provide adequate schemes of normative identification under the banner of cultural and legal diversity (van der Ven 2011) for the members of diverse subgroups, or does this type of codification hinder them from integrating into mainstream, albeit highly heterogeneous Canadian society? 
Over the last decade, the purpose of authorizing normative agency for the self-regulation of religious communities, in particular by Canadian Muslims, has been challenged. This paper combines different analytical strands of the Canadian discourse on normative order and cultural diversity. Its main reference is a legal case that goes back fifteen years ago and which, in unforeseeable ways, linked Canadians of Moroccan origin with Moroccans living in Morocco. The paper analyzes the different approaches that the actors assumed when assessing the situation then and now, while being fully aware of the vast normative transformations that have taken place in Canada and Morocco, two countries that continue to grapple with the complex configurations of normative plurality. My analysis of the vicissitudes of this dispute over a tenyear-period therefore contributes to the study of the complex interweaving of Islamic law and legal pluralism in Canada, as they have evolved in space and time. What makes this case exceptional is that the settlement of an international dispute has both reinforced and questioned the legibility and the scope of Canadian normative plurality. The paper relies on diverse reinterpretations, opinions, attitudes and responses by individuals and groups, some of them contemporaneous with the event, while others giving a retrospective interpretation of them. This case study is methodologically explored as a diagnostic event (Moore 1987), allowing for an analysis of a variety of discursive strands. Memorization and remembrance are central to ethnography as a way to emphasize the extent to which these interpretations and assessments are time-bound (French 2012). Although framed as biographical narratives, individual perspectives on the event are couched in a larger interpretive framework, thereby highlighting the degree to which subjective reconstructions are formed by the perception of objective constraints.

The analysis relies on fifty interviews, some of them with the central characters and others with individuals from their social environment who had knowledge of the case. In addition, the information collected - especially those concerned with the impact that the changing social, political and normative framework conditions might have on the reinterpretations of the incident - was discussed with four religious experts in Morocco, and twenty-five members of Moroccan civil society organizations in Quebec.

\section{Migration, mobility and discursive entanglements in the nomosphere}

International labor migration began gaining momentum and media profile in Morocco after the 1950s, when Moroccans left their country in search of greener employment pastures. The flow of labor migration from different strata of the Moroccan society was, and still is, mainly directed toward Europe, especially France, Belgium and the Netherlands, and more recently, Spain and Italy. But migration statistics do not reflect one important fact, namely that Canada is the preferred destination for migration. Out of the three million Moroccans living in the diaspora -roughly $10 \%$ of the total population- only an estimated 120,000 are based in Canada. The financial remittances of migrants bring in significant revenues for Morocco, as well as direct investments in the Moroccan economy, and reveal the enormous importance of migration to the state, which not surprisingly has pursued a policy promoting emigration. However, the efforts of the migrants to integrate into their host societies are not always met with enthusiasm

RECODE Online Working Paper No. 27

January 2014

ISSN 2242-3559 
in the home country. Moroccan citizenship is inalienable. Even if the state sanctions dual citizenship, it also exercises careful insight into its diasporic population, so that Moroccans in the diaspora continue to be embedded in a tight net of normative regulations (de Haas 2007 and Bilgili \& Weyel 2009). Maintenance of regular ties with Morocco is facilitated and regulated by the Moroccan government. In 2007, the government created a separate ministry (http://www.marocainsdumonde.gov.ma/) and an umbrella organization called the 'Council of the Moroccan community abroad' (Conseil de la Communauté Marocaine à l'Étranger, CCME: www.ccme.org.ma) in order to regulate the relationship between the diaspora, its multifarious civil society organizations, the home country, and the state.

In this context, religious life plays a constitutive role in state policies, with mosques, Islamic associations, and state-run religious organizations directly involved in exercising control over the religious life of Moroccan migrants. The 'Moroccan Council of Ulama for Europe' (Conseil Marocain des Ouléma pour l'Europe CMOE; or Conseil européen des oulémas marocains, CEOM) has been responsible for the religious life of Moroccan migrants in Europe since 2008. The Council is closely involved in the training of imams and it intervenes in all spheres of religion. In a parallel vein, the House of Morocco (Dar al-Maghreb: http://daralmaghrib.ca/) was founded in Montreal in 2012 as a cultural center, but is also devoted to providing religious education and assistance in religious matters.

All these normative, administrative, and cultural entanglements, notwithstanding the fact of transnational mobility, have exposed Moroccans living abroad to larger global forces and contexts. Facing the challenges of the new circumstances of life, Moroccan expats have claimed their right to cultural self-determination and free religious expression in their host countries. With such claims, they also expect to preserve their traditional values and their cultural and emotional attachment to Morocco. Integral to such claims is the right to internal self-regulation of migrant religious communities (e.g. Rohe 2011). Moroccans who strive for a better life abroad adapt to the new circumstances by transforming their lifestyles and assuming a distinct immigrant identity that sometimes is colloquially called 'culture beur'. Standing astride other cultures and remaining ambivalent between integration and heritage, they usually embark on a hybrid way of life and try to carve out a place of their own both in the host and in the home country. They do so by attempting to harmonize traditions and values, whether religious or secular, which result in discrete political and socio-cultural topologies. Those who do not migrate are also affected by this process, but not necessarily in the way the state institutions prescribe.

Moroccan migrants (also called MRE -Marocains Résidents à l'Étranger-or MDM Marocains $d u$ Monde) do not just preserve personal and kinship networks in Morocco. They also invest in the domestic economy, promote development initiatives, and help accelerate the influx of new ideas in Morocco. In this way they contribute to the transformation of traditional property and power relations. As far as religious orientation is concerned, migrants may also turn to their religious leaders in Morocco for guidance in religious matters and traditional values. On the occasion of their temporary stays in Morocco during the 'reunion season' in summer, Moroccan expats like to perform important religious rituals and rites of passage -such as engagements or marriages- in accordance with Moroccan popular Islam (Salih 2002 and

RECODE Online Working Paper No. 27

January 2014

ISSN 2242-3559 
Zillinger 2009). The impact of the MRE on the local, social and political conditions and the use of traditional knowledge to orientate their lives in their new environment, have attracted ample scholarly attention (Daoud 2005; Lacroix 2005; Sabry 2005 and Snel et al. 2006).

Our analysis here focuses on different aspects of such interactions between the diasporic Moroccans in Canada and the individuals, groups, and institutions in Morocco (von Benda-Beckman et al. 2005). Other issues, like the translation of monetary, cultural, and intellectual remittances into new local realities, or the revitalization of tradition and the return to religious conventionalism in the diaspora (cf. Bowen 2004), are of peripheral concern in this paper. Instead, the analysis centers on a shared 'translocal normative space', which refers to an overarching normative order providing a frame of reference for dispute resolution among the Muslim diaspora outside of the national judiciaries. In our case, actors on both sides of the dispute consider this religious framework of normative Islam as the unifying bond between Moroccans and Canadians of Moroccan origin.

Claims of legal autonomy and for the self-regulation of religious communities may thus involve transnational relations. The transnational configuration of this particular case demanded what I term 'translocal dispute management' conducted under the presumption of a homogeneous translocal normative space as its valid frame of reference. However, the ethnographic method defies the veracity of such presumption, as it reveals the existence of heterogeneous religious attitudes and diverse regional interpretations of Islamic norms. The interviews made during the field study show that the attitudes toward communitarian selfregulation depend on the socio-cultural environment and reflect the different national legal frames of reference. The shifting parameters of a translocal normative space are exemplified in the reactions of the actors, their responses, and their retrospection at various time intervals, which in turn reflects their own embeddedness in the changing interpretive frameworks.

\section{A local dispute and its translocally arranged settlement}

The case here analyzed anticipates the time when the public debates on the relations between law and religion were commonplace in both countries. However, in 1999, when I began pursuing the story in my fieldwork in Morocco, this was on the lips of everyone in the Moroccan bled (home country). ${ }^{1}$ In the summer of 1999, when the vaccancia, the zmagria or saffarin, as Moroccan residents abroad are locally called, visited their native bled -in this instance a village in the Moroccan Souss plai - a discussion ensued between the local Souassa the people of the Souss, in southwest Morocco- and migrants from various host regions and countries. Among them were internal migrants, who had moved from the Souss to Casablanca

\footnotetext{
${ }^{1}$ The people and places to which this article refers have been kept anonymous. The data were collected during fieldwork in Morocco and Canada in 1999, 2003, 2005 and 2011, and by use of communication technology and interviews during the period between 1999 and 2012. Quotations are my own free translations. Since 2005, this research has been part of a project on "Legal Diversity within and beyond the scope of the state: debating and practicing faithbased dispute management in emerging transnational networks connecting Morocco and Moroccan migrant communities in Canada" within the Project Group Legal Pluralism; since 2012, within the Department of Law \& Anthropology at the Max Planck Institute for Social Anthropology in Halle/Saale, Germany.
} 
in search of employment, and the MRE from various host countries. The latter group included two representatives from Montreal, home to the largest community of Canadiens d'Origine Marocaine, a term the two gentlemen invoked to identify themselves.

\section{Moroccans' dreamland}

The discussion revolved around the classification of the different groups of MRE according to their host countries. A discussion ensued on the most desirable destination for Moroccans away from their home country. Surprisingly, the consensus among the discussants was that "Quebec, of course, is the dreamland for Moroccans." I could imagine the reasons for that response: Moroccans migrating to Canada have to be well educated in order to meet the Canadian immigration requirements. They often come from well-off families and are expected to attain a better standard of living than those migrating to European countries. Moroccans, moreover, also hold Canada in high regard as a reliable partner in development cooperation. But when I specifically asked about the preference for Canada, the response was somehow unexpected: "Because it is like an Islamic country!" In response to my surprise, the following explanation was offered: "Moroccans there are free to exercise true religion, and there is greater acknowledgement of Islamic law there than here in Morocco. And sometimes, when they don't know exactly how to handle Islamic issues they are not familiar with, we are ready to support them." It turned out that all my interlocutors were aware that Canada was hailed as "une terre d'Islam sans musulmans" (cf. Azizi 2008). Some of the reasons enumerated in the discussion were not really related to Islam in the way I had expected, as they affirmed that the protection granted for religious freedom and diversity within the Canadian judicial framework did not eschew the spiritual practices of popular religiosity.

\section{The dispute between Na'ima and her landlord}

In order to illustrate their argument my interlocutors -Souassa and Quebecers- referred to a specific incident that had attracted much interest throughout the whole region. In the subsequent years I followed the case and discussed it with many of the persons involved. The story began in 1998: 'We once sent a legal expert from here, a Soussi faqih, to help them solve a legal dispute.' 2 This is how the matter was introduced to me. After some clarifications, I understood that the two scenarios were in fact interconnected: what started as a Moroccan affair involving Moroccan protagonists subsequently led to a much debated entanglement in a Canadian dispute that was brought before the Civil Division of the Court of Quebec (Chambre Civil de la Cour $d u$ Québec) by a Canadian businessman of Moroccan origin.

The dispute itself centers on Na'ima, the daughter of a Soussi farmer, politician and a member of the rural elite, who in the 1990 s was a student of ophthalmology in Montreal.

\footnotetext{
${ }^{2}$ The term faqih translates as an expert in Islamic law. In the given context, however, there is an apparent semantic extension, since the mentioned expert is also considered a Sufi shikh, meaning a representative, a leader of a spiritual mystic orientation in Islam. Mainstream Fuqaha (plural of faqih) usually keep a critical distance from Sufism. All my interlocutors widely ignored these distinctions and explicitly talked of a Sufi faqih.
} 
Na'ima's background positioned her in the Moroccan upper class even in the eyes of other members of the Moroccan community around Montreal. Moroccan elite students in Canada are regarded as the most privileged group in Morocco. After some years in Montreal, shortly before she was due to take the final examination, $\mathrm{Na}^{\prime}$ ima suddenly took ill. Her symptoms included heavy headache, sudden anxiety attacks, avolition, reduced intake of food, and so on, but the cause remained unclear and medical treatment in Canada had not been successful. Her parents forced her to return to Morocco for further treatment. She reluctantly agreed, but the medical treatment in Morocco also failed.

Since her condition further deteriorated, her father consulted a well-known local Sufi expert, shikh Abdesslam al-Youssi, a person of considerable repute in the spiritual treatment of such ailments. His diagnostic was 'spirit possession', a generally accepted conjecture based on the shared belief in the communality between humans and spirits (jnun). As sapient creations of God, spiritual beings claim the same physical space as humans, often leading to uneasy entanglements, to which Na'ima's symptoms seemed to bear credence. Discourses on spirit possession abound for that reason and are attributed to a variety of factors (Dieste 2012), but as children of wealthy parents are regarded as particularly vulnerable to spirit possession, Na'imas struggle in itself did not elicit much surprise, even if her diasporic condition rendered the solution more complex.

Representatives of religious congregations (turuq) and Sufi experts in Morocco are empowered to intervene and negotiate in matters relating to the co-existence of humans and the jnun, as they are believed to possess the requisite knowledge and acumen (trance techniques, for instance) to perform acts of mediation. The diagnosis of the Sufi faqih Abdesslam al-Youssi confirmed the father's suspicion. But when all attempts to free his daughter from the spirit had also failed, the faqih took the spirit's refusal to mean that it could conceivably not be Moroccan, but Canadian, or maybe exclusively francophone, and would only agree to the release $\mathrm{Na}$ 'ima in his/her home country. Such a view was not out of step with the prevailing discourse in Morocco, where theories on 'globalization of the spirit world', the increasing influence of the 'transnationally active spirits' on the national economy and agriculture, or even the increasing mobility of jnun and the prevalence of foreign spirits conversant in foreign languages freely circulated. Some suspected the 'foreign spirits' of causing plant diseases that jeopardized cash crop exports. The presumed transnationalization of wandering spirits forced increased deployments of Moroccan religious experts among migrant communities abroad. In short, the case explored here was not considered out of the ordinary (e.g. Dumont 2004).

$\mathrm{Na}$ 'ima, her father, and the faqih discussed the matter over the ensuing weeks and since the young woman did not recover, her father suggested that the faqih should accompany her to Montreal in order to exorcize the spirit there. Shikh Abdesslam refused pointblank, as he had only travelled abroad some 20 years ago for the hajj (pilgrimage to Mecca). Undeterred, the father held out the prospect of a huge sadaqa (voluntary charity) and promised all possible travelling comforts. Within a matter of a few weeks, the faqih acquiesced and travel preparations were soon underway. A private aircraft was chartered for him and his entourage of twenty persons -it must have been a memorable spectacle to see the faqih in his full vestments travelling to Montreal. Upon arrival, he immediately started investigating. After concluding that

RECODE Online Working Paper No. 27

January 2014

ISSN 2242-3559 
Na'ima's flat had been spiritually contaminated, he made plans to cleanse the apartment of all negative forces.

Meanwhile, Na'ima's landlord -not having been informed about her whereabouts and circumstances- had filed a suit seeking her eviction owing to rent arrears accumulated over the months she had spent in Morocco. Na'ima's father, who accompanied the traveling entourage, intervened and negotiated with the landlord, a Canadian businessman of Moroccan origin as it turned out. Despite several attempts at rapprochement, the parties were unable to arrive at an agreement, especially because the Souassa insisted the amount under dispute to be reduced, citing as reason the landlord's involvement in the spirit possession and the contamination of Na'ima's apartment. ${ }^{3}$ The court hearing eventually did take place.

The attorney who had been engaged by Na'ima's father called shikh Abdesslam alYoussi as the expert witness, who set out to explain the behavior of the defendant and testified that $\mathrm{Na}$ 'ima was still too sick to appear in court and that her ailments had rendered her unable to pay her rent in due time and caused her to suddenly flee the country. In his testimony, the shikh also raised the suspicion of the landlord's involvement, which, according to him, could not yet be precluded in light of the mysterious illness, suggesting that further investigation needed to be conducted by an 'experienced' person (the shikh himself) who could be relied upon to get to the bottom of the case. The implication was that the actual reason for Na'ima's sickness was the haunted flat for which the landlord was to be held responsible. According to the information I received after the shikh had taken the stand, the judge had interrupted the court hearing saying, "you know what, gentlemen; the parties should first be given the opportunity to come to an extra-judicial, internal arrangement".

The landlord immediately agreed, but according to my interlocutors, he was acutely embarrassed over the implication that he was expected to tolerate such atavistic practices as exorcism merely owing to his ethnic and religious background. He would have preferred to avoid the legal action altogether had he known that it would entail tense dealings with someone like shikh Abdesslam al-Youssi, who in Quebec visibly fell out of the ordinary. The judge's ruling, which allowed the parties to first attempt mediation -a commonplace practice-, was reason enough for the shikh to vindicate his role and even to feel called upon by the Canadian court to mediate the dispute between the three sides -two human and one spiritual. Moreover, given his reputation as an erudite scholar of Islam, the landlord had no option but to relent and accept him as the mediator.

At Abdesslam's insistence, Na'ima's father was willing to pay off the back rent under the condition that the landlord would cover a portion of costs relating to the shikh's travel and the cleansing rituals for the flat. Both parties accepted the deal and sealed it with a prayer. With regards to the role of the judiciary, the litigants affirmed having received an official approval from the presiding judge at the Civil Division of the Court of Quebec afterwards. Therein, the

\footnotetext{
${ }^{3}$ Various factors may have contributed to the breakdown of negotiations at this stage. It was not a question of money. The father could have paid the due rent easily. There were serious suspicions regarding the role of the landlord because he was Moroccan, and envy is often considered to play a role in cases of spirit possession. In addition, maybe the old and established antagonism in Moroccan society between Soussi -the people from the rural Souss, in southwest Morocco- and the urban educated Arab elite from Fez, to which the landlord's family belonged, may have played a role.
} 
dispute was classified as a business case to be subject to the informal arbitrament of shikh Abdesslam al-Youssi under Islamic law. A Canadian civil case thus came to be redressed under Islamic law within the confines of the Muslim community.

As arranged, the faqih successfully negotiated with the spirit who, as it turned out, was after all a Quebecer. The spirit absolved the landlord of the accusation of complicity and stated that he had chosen the flat by free will. In exchange for some small benefits, the spirit finally agreed to withdraw. No one with the exception of the persons involved had taken notice of this case of spirit possession and its informal settlement with the court's seal of approval. The newspapers had not published the story, and the landlord had paid scrupulous attention to ensure that the incident was kept under wraps.

Immediately after the exorcism had been performed, the Moroccan entourage travelled home. Although now free of her ailments, Na'ima chose to first recuperate in Morocco before returning to Montreal to complete her studies and pass her medical exams. She continues to live in Montreal as a Canadian citizen and is a practicing ophthalmologist. Married to a medical doctor of Lebanese origin, she visits Morocco over the summer like other MRE.

\section{Contingent perceptions and assessments}

The ethnographic description is particularly instructive because it shows its embeddedness in overlapping normative and religious spheres. While it directly involves Moroccans in Morocco, a Moroccan student in Quebec, and a Quebecer of Moroccan origin, the incident must be viewed within the framework of cultural and legal diversity under Quebec law, which had been brought to facilitate an internal dispute regulation within a religious community on a matter bearing spiritual and economic dimensions. An analysis of the changes in the assessment of the case by the circle of actors involved over a decade, reveals the interplay of transnational and national contexts, as well as the combination of different approaches and epistemologies.

\section{Interpreting Na'ima's fate}

For the Souassa involved, the affair proved the veracity of the rumored transnational network of spirits. The measures they had developed to cope with the transnational spirit movements had also proved to be effective. Shikh Abdesslam al-Youssi voiced the opinion that Sufi witness experts would be able to contribute to the settlement of disputes bearing elements of popular religiosity, such as the use of 'love magic' or curses, believed to work seamlessly over physical borders, some apparently even causing impotence. Most of the Moroccans involved in the case expressed their satisfaction with the way it had unfolded and with the final outcome, which in their view had established without a shadow of doubt that the local techniques of dispute settlement, far from being antiquated, remained pertinent even in transnational multicultural settings. But some deplored the growing cultural and religious alienation of emigrated Moroccans precisely at a time when the globalization of this type of phenomenon was being vigorously discussed. In the majoritarian view, the case proved the existence of a shared religious and legal identity that connected locals with migrants. Quebec was praised for its superior regulatory environment, which they felt offered a more favourable environment for 
religious dispute management than Morocco, and displayed greater sensitivity toward the matter at hand. ${ }^{4}$

In contrast, the Quebec businessman, who was mortified by his involvement in this debacle, offered an entirely different perspective: "they still live in the middle ages,' he said. 'I want no part of it. Sure, I am a Muslim, but not of this kind! It is unbearable to even contemplate the consequences if the Canadian public knew of the case. I have less in common with such people than with my Hindu neighbors. "Nevertheless, he also expressed his respect for the Moroccan sensitivities and maintained that the verdict of the faqih had been the best way out of this situation.

The Quebec judge, in turn, had not bothered to consider to what extent the problem with a spirit might fall in the category of a cultural dispute (Dundes Renteln 2004), especially as an expression of cultural diversity, and classified the case as an internal religious dispute. The claimant's preference for a formal court verdict, instead of an informal arbitration, had been overruled owing to the judicial acknowledgement of the terms of a religious/medical intervention from his home country where, ironically, such cases never reached the official judiciary for settlement. Nevertheless, the informal legal interaction between members of diverse communities presupposes a compliance with the basic markers of a shared legal identity, allowing them to agree upon an informal set of rules, be they based on religion, local culture, origin, professional codes, or visual similarities. But this picture suggests that the construction of such commonalities out of the repertoire of 'diversities' creates a transient, yet 'instant shared identity' modeled to resolve disputes that are not so infrequent. As was said before, the story did not arouse much interest in 1998 beyond the confines of the two communities in Quebec and the Moroccan Souss, with whom the actors are linked. All the protagonists agreed that the Civil Court of Quebec was an impartial institution that guaranteed a fair compromise in accordance with the Canadian law. No mention was made of religious accommodation or of the enforcement of the Islamic legal principles and so on.

\section{Reinterpreting Na'ima's case}

A decade later, the protagonists remember the case quite differently. They have changed their interpretations, but still agree that the case would not have unfolded in the same way under current circumstances. My Moroccan interlocutors were well aware of the new developments in the host countries of their migrant relatives and friends. The entourage that had accompanied the shikh assessed the case retrospectively as having exemplified the range of elements that should be ideally subsumed under the notion of normative Islam, even of Islamic law, but that continues to be marginalized. This 'legal shortcoming' was viewed as a problem both for Morocco and Canada. Restrictive trends in recent times have been the cause of much debate and disappointment, especially concerning the way in which cultural diversity in Quebec has been managed. Most of my interlocutors, however, expressed solidarity with the Canadian

\footnotetext{
${ }^{4}$ One of the criteria for the positive assessment of the way the Civil Court of Quebec dealt with the case was the comparison with the Moroccan judiciary. Although the legal capacity of the spirits is formally acknowledged in the religious scripture, Moroccan judges have refused in several cases to follow those terms, for instance in cases where claimants have applied for divorce from spiritual beings.
}

RECODE Online Working Paper No. 27

January 2014

ISSN 2242-3559 
MRE, who had taken a clear stance in the debate on cultural diversity in Quebec. They especially appreciated positions that stressed the importance of cultural ties with Morocco as the country of origin and as an integral part of their patterns of identification. Such positioning in the debate has raised the reputation of MRE among Moroccans, while the image of Quebec as the ideal destination for Moroccans had suffered some blows. In a similar vein, the Quebec businessman has also revised his views, now preferring to interpret the incident as an instance of the cross-cultural mediation skills of the representatives of a special strand of spiritual Islam practiced by Moroccans. 'Yes, that was quite smart how the shikh then managed to settle the case without ever challenging the Canadian legal system.' Then he added, 'and also the judge was cool. I don't want to know how such a muddle would turn out nowadays'. In recent times, attempts to reinterpret the case and to recollect how it unfolded over time have been on the rise both in Morocco and Canada.

\section{Changing framework conditions}

Why had the protagonists chosen to modify the assessment of their earlier experience in the interim period? In what ways did this change of opinion reflect a palpable transformation of the normative, social and political frame of reference? To what extent might this change have affected the idea of overlapping religious communities forming one overarching and coherent unit, with its members sharing the same religious normative order? All of these may affect how consensus is established in the self-regulatory practices of a community.

Both countries have witnessed considerable changes in the public mood and opinion, so that legal discourses have given rise in part to a reverse trend. Canada and Morocco have modified the scope of legal agency in the context of internal dispute settlement. Canada, and Quebec in particular, which are usually lauded for their outstanding protection of cultural diversity, have gradually restricted the space for legal agency within such framework, while Morocco has sought to expand the legal role and scope of Moroccan Islam in response to the increasing influence of political Islam.

\section{Moroccan transnational normative integration and the challenge of political Islam}

Moroccan interpretations were largely shaped by the national debate on the judicial reform, which started in 1999 with the enthronement of King Muhammad VI (Maddy-Weitzman and Zisenwine 2012). This process somehow set in motion antithetical trends. On the one hand, political liberalization was palpable in the years between 1998 and 2009 (Bendourou 2004). As a part of the cautious politics of neoliberal integration, concrete steps were taken toward democratization and decentralization (Storm 2007), civil society initiatives (Sater 2007), and market liberalization (Cohen 2003 and Cohen \& Jaidi 2006). On the other hand, restricted freedom of the press, increased state control, and the expanded role of public security forces to contain Islamic activism undermined those liberalizing strides. This was especially the case after the 2003 bombing attack in Casablanca. After being attributed to Islamic terrorists, the attack led to a modification in the security legislations in order to attune it to transnational antiterrorism laws. As a result of this, the spread of political Islam throughout the country was 
restricted (Turner 2007). ${ }^{5}$ In the shadow of these developments, the 2004 reform of the Moudawana -the Moroccan personal status code- endowed the country with the most modern family law in the Middle East and North Africa area (Foblets and Carlier 2005). Furthermore, the government started a campaign advocating a Moroccan interpretation of Islam in order to integrate the diverse local strands of Islamic piety, while the Moroccan ulama expressed their distaste for transnational political Islam (e.g. Maghraoui 2009 and El Katiri 2013). In 2004 and 2005, a Truth and Human Rights Commission was established along with the Equity and Reconciliation Commission (Instance Equité et Réconciliation - IER), which accounted for the so-called 'Years of Lead' (the period comprised between 1956, when Morocco regained its independence, and 1999, when Hassan II passed away; e.g. Wilcox 2009).

More recent developments have led to an insistence on an 'accurate' reconstruction of the case. Protests in Morocco since 2010, in the wake of the Arab Spring, have paved the way for a constitutional reform. In the aftermath of the national elections held in 2011, that brought victory to the Islamic Parti de la justice et du développement (PJD; García 2012), the role of the diverse components of Moroccan legal pluralism are being reconsidered. Such reflections also include concerns about the impact of religious groups on legal debates and the law-making process. With the constitutional reform of 2011, the scope of the monarch's power came to the fore, especially his role as the religious head of the country. Moreover, the notion of religion as a unifying bond also came under scrutiny, as the Moroccan diaspora was associated with a transnationalization of Islam.

\section{Canadian politics of cultural diversity}

The Canadian legal system, in contrast, is internationally renowned for its ambition to regulate cultural diversity. While the Canadian concept of legal pluralism refers to state-recognized correlations between Common Law, Civil Law, and Aboriginal rights (Constitution Act, 1982; Section 35). Informal legal practice is constitutionally regulated under the Canadian Charter of Rights and Freedoms. However, intense public debates have recently demonstrated the fragility of the cultural diversity model. Three controversial debates are the background against which this case must be reinterpreted. Between 2003 and 2006, a first debate occurred in the province of Ontario as a reaction to an announcement posted by an Islamic organization on its website offering to perform shari'a arbitrations in Canada. The general perception was that shari'a law would be introduced as the binding legal basis for informal arbitration among Muslims. The second debate revolved around divergent interpretations of some cultural practices as contributing to the segregation of certain ethnic communities in Quebec. As a result of the debate, a commission was established to develop proposals for those problems (the so-called

\footnotetext{
${ }^{5}$ In that same decade, between 1999 and 2009, Morocco, and especially the Souss, was transformed by the Islamic movement of the Salafiyya (Chaarani 2004; Zeghal 2005). This religious movement proposes a general reorientation toward an 'authentic,' 'original,' and uniform Islam throughout the Muslim world. Their interventions in a variety of local legal matters provoked a plethora of conflicts. Competition among adherents of different streams within normative Islam had an impact on the established legal order. Besides customary, national, and transnational law, the sphere of religious normativity has been diversified. Such changes did not go unnoticed in the interactions between Moroccans in the Souss and their migration network.
}

RECODE Online Working Paper No. 27

January 2014

ISSN 2242-3559 
Bouchard-Taylor Comission). The third episode, yet to be debated in the media, concerns Muslim women wearing the veil in public and the legal restrictions on their access to public services in general.

\section{Sharia law dispute in Ontario}

The question raised in the shari'a debate concerned the compatibility of Islamic law with the Canadian constitution in light of the Ontario Arbitration Act of 1991, which stipulated a legally binding arbitration beyond the bar on the condition that requisite standards were met and the final settlement in no way infringed on the Canadian law. This included faith-based arbitration in private matters, mostly involving familial disputes that previously had attracted no attention despite widespread practice within religious communities.

In 2003, the announcement by a Muslim organization that it was prepared to provide arbitration in accordance with the Islamic law was understood as an attempt to introduce 'shari'a law' in Canada and triggered a vehement dispute over the compatibility of Islamic law with Canadian legislation, particularly over the legal and social status of women in Islamic law. Despite concrete suggestions for a reform of the Arbitration Act made by an official report (Boyd Report 2004), which would enable the practice of religious arbitration to continue, the scope of the Act was restricted. The debate only faded away in 2006, when an amendment to the Arbitration Act excluded all forms of faith-based arbitration (Emon 2006; Korteweg 2006 and Razack 2007).

\section{CCPARDC in Quebec}

In contrast to Ontario, faith-based arbitration of familial matters was always prohibited in Quebec. The Ontario example, however, fuelled an ongoing public debate in Quebec on multiculturalism, cultural accommodation, and mutual tolerance within the framework of cultural diversity. In this debate, a number of incidents were blown up by the media. In February 2007, the provincial government created the Consultation Commission on Accommodation Practices Related to Cultural Differences (CCPARDC), also known as 'Commission on Reasonable Accommodation' or 'Bouchard-Taylor Commission', and named it after the two well-known social scientists, Gérard Bouchard and Charles Taylor, who had been commissioned to study 'reasonable accommodation.' The debate on reasonable accommodation did not actually address the issue of legal diversity per se, but was concerned instead with multicultural tolerance and problems for coexistence in a multicultural environment. From a juridical perspective, the excessive judicialization of cultural accomodation was criticized, as reasonable accommodation of religious and cultural beliefs was portrayed as a right that could be legally claimed.

Upon investigation, the commission issued a 300-page report a year later (Bouchard and Taylor 2008). In addressing the anxiety felt by many Quebecers about how the reasonable accommodation clause would affect their identity, the commission basically stated that the time had come for Quebec to get over its collective identity crisis and adapt to a secular, pluralistic society. It summarized data from the public hearings and regional forums, research projects, and 900 briefs submitted by groups, individuals and associations. The authors criticized the 
heated tone of the public debate for having been largely fuelled by a 'crisis of perception' and by distorted media reports. Canadians of Moroccan origin were among the many minority groups targeted in the debate. They stood out for the interventions they had made both collectively and as individuals, not because the spotlight was cast on their Moroccan background, unlike members from other Muslim communities who emphasized their cultural background and ethnic markers.

Some incidents, however, attracted the attention of the anti-Islamic francophone website 'Point de Bascule Canada' (http://www.pointdebasculecanada.ca/). Such 'news' have been implicitly associated with the accommodation debate, as intending to demonstrate the inability of Moroccans to integrate into Quebec society and the general threat Muslims pose to Quebec identity. The story of the 'good Moroccan' whose conversion to Christianity eventually rendered him paraplegic is fairly well known. He had fallen casualty to the wrath of his former community members, who pushed him off the balcony accusing him of apostasy after all the attempts to reconvert him had failed (Point de Bascule 2007). Canadian-Moroccans felt particularly scapegoated when the same media published distorted accounts of how Islam was practiced in Morocco. Referring to a reputable survey on religion in Morocco, undertaken by three highly respected Moroccan scholars (el Ayadi et al. 2007), Point de Bascule published an article headlined: 'Les Marocains musulmans sont moins tolérants que les Québecois' (Moroccan Muslims are less tolerant than the Quebecers; Lessart 2007). This polemical reading offended many Muslims, who felt the scientific nature of the publication had been challenged. The exceptional case of an overtly public and critical debate on religious matters in Morocco was not seen as a first step toward freedom of expression, but as evidence to the contrary. The independent Moroccan weekly magazine Tel Quel, to which the polemics referred, stated: "A society that diagnoses its omissions is granting itself a chance to cope with its deficiencies" (Iraqi 2007). ${ }^{6}$ In fact, the study commissioned by the Moroccan government and financed by the German foundation Friedrich-Ebert depicted as a general hypothesis, the increasing secularization of Moroccan society. This, however, could not be extended to Moroccan society as whole, as contradictory trends could also be observed. In other words, the study showed that Moroccan Islam and Islamic pluralism in Morocco offered a multifaceted but incoherent picture, with a multitude of Islamic identities that also included some traditionalist and intolerant tendencies. Point de Bascule had twisted the tenor of this publication right around.

Many members of the Moroccan Muslim community expressed their disappointment with the debate on reasonable accommodation and with the polemics that had been voiced against Muslim immigrants. In particular, the incompatibility between 'laicism' and 'multiculturalism' publicized by the admonishers of cultural infiltration offended Canadian Muslims, who lived under the illusion of having inherited both a Canadian and a Quebec identity. ${ }^{7}$ The controversy revealed in all seriousness the ambiguous position of Quebecers towards their visibly different compatriots.

\footnotetext{
${ }^{6}$ Nevertheless, there was also true-to-fact information in the Canadian news that shed light on the public interest in the Moroccan survey; see e.g. Marechaud 2007.

${ }^{7}$ See also Jedwab 2006 for a general assessment of Canadian Muslim's sense of belonging to a Canadian nation.
} 
Since its publication in May 2008, the final Bouchard-Taylor report has received ambivalent reactions. Conservative politicians voiced concern that Quebecers could no longer define themselves in terms of their French-Canadian heritage, while reactions from community organizations were positive (Sharify-Funk 2010). The Bouchard-Taylor commission did not challenge self-identification or externally ascribed identities. Thus, identity categorizations are likely to retain their significance in legal matters. It remains to be seen to what extent crosslinkages based on one single criterion of identification, such as religion or 'culture,' can overcome the differences based on other criteria when it comes to informal legal interaction.

Parallel to the changes in the political and religious landscape of Morocco in the wake of the Arab Spring, another heated polemic unfolded in Quebec about the display of Muslim markers, particularly the public usage of the niqab (face veil). Bill 94, a legislation prohibiting women from publicly wearing the veil or from gaining access to public services, was already in preparation. Although this issue did not directly address the concerns of the Moroccan expats, since they did not consider the niqab as integral to their faith, they felt drawn into this alienating discourse. ${ }^{8}$ The controversy, which has not yet been resolved, has intensified the ambivalence felt by immigrant Canadian-Moroccans, who follow the developments in the Arab world with great concern, especially those in Moroccan politics, while facing the new challenges to their freedom of religious expression in Quebec. The niqab controversy had a particular impact on the debate on legal agency and on the access of Muslims to justice. Part of the debate was related to the question of whether Muslim women should be allowed to appear veiled in court and exercise other fundamental rights accorded to citizens in general (SharifyFunk 2011 and Choudry 2012).

A new perspective: Na'ima's case as an example for internal legal procedure in religious communities

It was in the light of these debates that the actors involved in the $1998 \mathrm{Na}$ 'ima case expressed their ambivalence in 2008 and 2012, and emphasized the multiple legal identities of Canadian Muslims of Moroccan origin. Their emphasis underlined the challenge of reconciling two often incompatible demands, namely that of preserving meaningful legal and cultural ties with Morocco without forfeiting the possibility of full legal integration into Quebec society. Canadian MRE, as the argument has been made, are fairly emancipated from their Moroccan legal background despite preserving their affinity to Islamic normative thinking, since the latter offers a strong link to their country of origin. They inferred not only that they had not been sufficiently recognized in the 'accommodation debate', but that the terms of their inclusion in the Canadian legal framework also remained ambiguous. Despite all their past efforts to affirm integration, they were only partially accepted and recognized. This ambivalence also found expression in a more positive assessment of their legal heritage than before.

\footnotetext{
${ }^{8}$ There is a flood of publications around the topic, especially targeting the situation in European francophone countries such as Belgium and France. This allows integrating the niqab- and burqa-banning debate in Quebec into a larger discourse in Western liberal democracies. In francophone societies, the French concept of laicité has exerted an important influence on the restrictive attitude toward Muslim claims. See e.g. Carol/Koopmans 2013; Sharify-Funk 2011; Leane 2011.
}

RECODE Online Working Paper No. 27

January 2014

ISSN 2242-3559 
Canadians of Moroccan background who knew of Na'ima's case preferred to maintain a discrete silence. Citing the tense atmosphere in the wake of the debate on reasonable accommodation, some felt that an informal dispute settlement of that sort would be unimaginable in the present context. Furthermore, with all the negative press the Moroccans in Quebec had received during the heated period of the debate, it seemed impossible to imagine the former prevalence of religious tolerance in Quebec.

\section{Multiple normative identities?}

In the case concerning Na'ima's outstanding rent, the landlord, a Canadian Muslim of Moroccan origin, had first insisted on a formal legal regulation before acquiescing to an informal settlement. Asked about it today, he contends that this concession was synonymous with the notion of reasonable accommodation, as the court had simply assented to whatever he had accepted. A certain reservation resonates from this assertion, namely, that in legal matters, external identity markers allowed translocal interactions to supersede the normative identities deriving from Canadian law. This aspect allows us to address the epistemological insights into processes of identity formation through the lens of this dispute. A situation of conflict, as the one outlined above, compels a disclosure of values, convictions and loyalties (Schlee 2004). In how it is remembered, the Na'ima case shows that Canadian-Moroccans actors now use the discourse of reasonable accommodation in legal matters to model identity-based legal frameworks. They do this by accommodating their convictions to their migrant condition, thus showing that their internal normative order is embedded in the values of the host country, and conforms in fact to the Canadian notions of civil liberties, human rights and cultural diversity. Legal institutions therefore produce powerful identity markers capable of creating communities with different repertoires of identification (Eisenberg and Kymlicka 2011).

Charles Taylor (Bouchard and Taylor 2008) has argued that the peculiar condition of Quebecers as a minority within Canada shapes their restrictive attitude toward reasonable accommodation. There are two important markers working in this sense. One is the unique judiciary of the Province of Quebec that links it to a legal universe where private matters are regulated under civil law, in contrast to the common law tradition of the rest of Canada. Secondly, with French as its administrative language, Quebec is more closely connected to other member states of the International Organization of the Francophonie. The Quebecers of Moroccan origin regard language as the distinguishing element they share with other Quebecers, and which sets Quebecers apart from other Canadian citizens. On the battlefield of reasonable accommodation, which also governs the most sensitive issue of linguistic diversity, 'Moroccans' thus occupy a more privileged status. Given the minority status of francophone Canadians within the country and the peculiar political discourse on the 'Quebecer' identity, the FrancoArabic bilingualism of Moroccan-Canadians singled them out as linguistic compatriots, especially in comparison to other non-Maghrebian Muslims. In our conversation, the Moroccan civil society activists emphasized that Canadian MRE would have appreciated seeing an analogous identification of commonality in legal matters, given the shared affinities with the French legal system and the colonial history. In light of the debates on faith-based arbitration

RECODE Online Working Paper No. 27

January 2014

ISSN 2242-3559 
and reasonable accommodation, the $\mathrm{Na}$ 'ima case was remembered retrospectively as reasonable accommodation avant la lettre.

These reflections on processes of migrant (normative) identity formation coincided with the public discourse in Morocco (Benjelloun 2002 and Rachik 2003), which stressed the challenges that emigration and the accelerated integration of the country into a globalized society posed for the traditional canon on national identity. This is made out of five identity markers, namely African, Berber, Arab, Mediterranean and Muslim. With religion as a component of Moroccan identity, the legal dimension of religion cannot be overlooked, since it provides an overlapping normative link with the Moroccan diaspora. So far, normative Islam has been discussed as a shared normative identity.

\section{External view on the case}

My discussions in 2009 and 2011 with activists in the newly emerging Quebec-Moroccan civil society organizations in Montreal and Sherbrook on issues of legal agency and communitarian legal action added new dimensions to the assessments referred to thus far (see http://www.maghreb-canada.ca/). Canadian Moroccans view their scope of action through the Quebec model of protection of legal diversity. Most interviewees, however, believed that this state-guaranteed model not only provides a space for legal interaction for diasporic Moroccans, but also for peoples of different backgrounds. Contested notions of multiculturalism, human rights, gender equality, and Canadian identity as a nation of immigrants resonate against the broader backdrop of the debate. The internal debates of the civil society organizations emphasized the primacy of Canadian law and the formal dependence of communitarian legal agency on the general framework of state law. They saw the right to internal regulation as being protected under Canadian law, but also protected against the imposition of some interpretations of their normative repertoires by external religious authorities. Internal regulation within the religious communities was thus seen as compatible with the Canadian legal framework and not being an infringement of the tenets of integration. Interestingly, the civil society activists believed that, under comparable circumstances, the Moroccan state agencies charged with the religious supervision of the expatriates would nowadays intervene and 'bring in a religious expert' such as shikh Abbdesslam. There was general agreement that the Moroccan state was well aware of the intensity of informal religious interactions between the home country and its diaspora.

\section{Shared and non-shared strands of interpretation}

The Moroccan reimagining of the Na'ima case was predominantly influenced by the legal developments within the home country and by the fact that the rural population is being integrated into transnational Islamic networks at a more rapid pace. The actors involved, as well as many others in Moroccan communities with diasporic population, followed the political process in Quebec with great interest, in particular the debates on accommodation and the politics regulating Muslim visibility in the public space that involved Canadian-Moroccans. The parties involved in our case nowadays stress the family law component of the conflict, which they associate with faith-based arbitrations in family matters, an issue intensely discussed in

RECODE Online Working Paper No. 27

January 2014

ISSN 2242-3559 
Canada. While this association hardly addresses the facts at hand, it does follow the internal logics of the duty of care that Moroccan families feel obliged to exercise, for instance toward a daughter (e.g. Bourqia 2006). Although initially the parties had not even considered the family law dimensions of the process, by 2009 this mindset had changed. The prevailing consensus now was that it expressed the typical Moroccan family sentiment. The gender aspect was also positively evaluated, as both sides had come to believe that "this extraordinary judicial case offered the young woman the necessary options to pursue her own ideas of life." Similarly, both sides also understand that the apparent tensions between the two worlds in which Na'ima was straddled, and the divergent expectations and challenges may have contributed to her illness. Caught between family responsibilities, her academic pursuits, and the prospect of adjusting to the new living conditions in Canada, such a young woman would have been especially predisposed to the described cluster of symptoms.

Moroccan and Canadian interpretations of what we could call a translocally shared space for internal normative regulation within a religious community were similar, mostly owing to Islamic activism in Morocco. The increasing impact of Islamic activists on legal affairs in Morocco since 1999 reverberates in both countries and there is tacit agreement that state suppression of Islamic rigorists would help preserve informal legal practice. Recent shifts in Moroccan politics have strengthened this perspective in the wake of the Arab Spring and the involvement of the PJD, the Islamist party, in the government since November 2011, especially with the appointment of the new Prime Minister. Both the advocates of popular Sufi Islam and the liberal Muslims in Quebec still interpret the intervention of shikh Abdesslam al-Youssi in positive terms. What the Canadians of Moroccan origin viewed at first as an exotic and atavistic strand of religiosity was later transformed into the memory of a positive expression of tradition and common roots. The majority of liberal Muslims in Canada nowadays regard this diversity as part of their cultural heritage. Now, both sides reinterpret their negotiations in the shadow of transnational political Islam and object to a dogmatic qualification of Islamic law (Mandaville 2001 and 2007; Roy 2004).

This aspect of translocality did not play a role in the deliberations of the Canadian judge. In her view, as she explained, it was a simple lawsuit involving a Canadian of Moroccan origin and a Moroccan student with a valid residence permit for Quebec. That lawsuit unexpectedly featured a religious dimension. From a Canadian legal point of view, the translocal dimension was non-existent, so the judge consented to an intra-community religious regulation of the case over a formal legal process.

\section{Conclusion: Looking back is looking forward}

This paper describes a case of translocal faith-based dispute management among members of the same, albeit internally differentiated, religious community. One party represents the religious majority in the home country, whereas on the other side constitutes a minority group in a multicultural environment. More precisely, the case illustrates the intricacies involved in the informal regulation of intra-communitarian religious disputes within the framework of Quebec's cultural diversity. Religious law, while not the unique platform for expressing

RECODE Online Working Paper No. 27

January 2014

ISSN 2242-3559 
commonality, quite often serves as the common ground in cases of dispute management. The reinterpretation of the incident has shown a large-scale transformation.

Cross references have been made in the interpretation of the event to show that the way this dispute was remembered a decade later was shaped by a series of religious and legal challenges in the two interrelated settings. Such development has produced a greater appreciation of Quebec's notion of cultural accommodation concerning the regulation of intracommunity disputes. It has also reinforced the cultural and religious ties to the country of origin. Perceiving the Moroccan contribution to the story simply as 'heritage' implies an admittance to a certain degree of emancipation from this repertoire of local knowledge. On the other hand, it also facilitates its transformation and adaptation to the new living conditions in Canada. The challenges of cultural and religious diversification in both countries have brought the protagonists of the case closer. Nevertheless, as shown before, the actors do appreciate the 'shadow of the state' in instances of extra-state dispute management. They insist on the need for an official compatibility check as a way to prevent the abuse of legal discretion.

To sum up, almost all the Canadians of Moroccan origin with whom I discussed this issue signaled their preference for an interaction with both legal repertoires. While they criticized discrimination in everyday life and subscribed to the notion of mutual tolerance for religious matters in multicultural societies, they did not claim a right to legal self-determination. They regarded the two strands of the public discourse -one on faith-based arbitration and the other on reasonable accommodation- as separate in principle yet connected. In the Quebec context, it is possible to observe that normative religion works as an identity marker for Canadian Muslims of Moroccan origin. Only occasionally may this be considered an identity marker that they share with Moroccans living in Morocco. Conversely, Moroccans in the Souss, who care about the resilience of local traditional Islam against transnational Islamic dogmatism, appreciate the positive evaluation that Canadian-Moroccans make of their religious heritage as their guiding principle for regulating internal problems. Conclusively, we can affirm that the integration of Canadians of Moroccan origin and Moroccan nationals into a transnational legal environment has generated greater freedom for making informed decisions concerning legally hybrid identities.

\section{References}

El Azizi, Abdellatif. 2008. "La recherche du Paradis.” Maroc Hebdo. Retrieved March 27, 2013 (http://www.maroc-hebdo.press.ma/SiteMarochebdo/archive/ Archives_435/html_435/recherch.html).

Benda-Beckmann, Franz von, Keebet von Benda-Beckmann and Anne Griffiths, eds. 2005. Mobile People, Mobile Law. Aldershot: Ashgate.

Bendourou, Omar. 2004. Libertés publiques et État de droit au Maroc. Fes: Friedrich EbertStiftung, Fesmaroc.

Benjelloun, Mohamed O. 2002. Projet national et identité au Maroc. Essai d'anthropologie politique. Casablanca: Éditions Eddif. 
Bilgili, Özge and Silja Weyel. 2009. "Migration in Morocco: History, Current Trends and Future Prospects." Maastricht Graduate School of Governance. Retrieved March 27, 2013 (http://mgsog.merit.unu.edu/ISacademie/docs/CR_morocco.pdf).

Boyd, Marion 2004. "Dispute Resolution in Family Law: protecting choice, promoting inclusion." Retrieved August 26, 2013.

(http://www.attorneygeneral.jus.gov.on.ca/english/about/pubs/boyd/).

Bouchard, Gérard and Charles Taylor. 2008. "Fonder l'avenir. Le temps de la conciliation. Rapport.” Report, Quebec. Retrieved March 27, 2013.

(http://collections.banq.qc.ca/ark:/52327/bs66285).

Bourquia, Rahma. 2006. "Société, Famille, Femmes et Jeunesse. Rapport Thématique." 50 Ans de Développement Humain Perspectives 2025. Retrieved December 18, 2007 (http://www.ondh.ma/Pdf_doc\%5CRap_THEM-SFFJ.pdf).

Bowen, John. 2004. "Beyond Migration: Islam as a Transnational Public Space." Journal of Ethnic and Migration Studies 30: 879-894.

Carol, Sarah and Ruud Koopmans. 2013. "Dynamics of contestation over Islamic religious rights in Western Europe.” Ethnicities 13 (2): 165-190.

Chaarani, Ahmed. 2004. La mouvance islamiste au Maroc. Du 11 septembre 2001 aux attentats de Casablanca du 16 mai 2003. Paris: Karthala.

Cohen, Shana. 2003. "Alienation and Globalization in Morocco: Addressing the Social and Political Impact of Market Integration." Comparative Studies in Society and History 45: 168-189.

Cohen, Shana and Larbi, Jaidi. 2006. Morocco: Globalization and its Consequences. New York: Routledge.

Daoud, Zakya. 2005. Marocains de l'autre rive. Les immigrés marocains acteurs du développement durable. Paris: Editions Paris-Méditerranée, Tariq.

Dieste, Josep L.M. 2012. Health and Ritual in Morocco. Conceptions of the Body and Healing Practices. Leiden: Brill.

Dumont, Dirk. 2004. "Vivre les invisibles." adr-productions France. Retrieved March 7, 2013 (http://www.adr-productions.fr/documentaires/vivre-les-invisibles,260).

Dundes Renteln, Alison. 2004. The Cultural Defense. Oxford: Oxford University Press.

Eisenberg, Avigail and Will Kymlicka, eds. 2001. Identity Politics in the Public Realm. Vancouver: UCB Press.

El Ayadi, Mohamed, Mohamed Tozy and Hassan Rachik. 2007. L'islam au quotidien - Enquête sur les pratiques religieuses au Maroc. Casablanca: Éditions Prologues.

El-Katiri, Mohammed. 2013. "The institutionalisation of religious affairs: religious reform in Morocco." Journal of North African Studies 18 (1): 53-69.

Emon, Anver. 2006. "Islamic Law and the Canadian Mosaic Politics, Jurisprudence, and Multicultural Accommodation." University of Toronto Legal Studies Series Research Paper $\mathrm{N}^{\circ} 947149$.

Foblets, Marie-Claire and Jean-Yves Carlier. 2005. Le code marocain de la famille. Incidences au regard du droit international privé en Europe. Brussels: Bruylants. 
French, Brigittine M. 2012. "The Semiotics of Collective Memory." Annual Review of Anthropology 41: 337-353.

de Haas, Hein. 2007. Morocco's Migration Experience: a transitional perspective. International Migration 45 (4): 39-70.

Iraqi, Fahd. 2007. "Statistiques exclusives. Quels musulmans sommes-nous?” Tel Quel, N³01, (December 8-14) Retrieved April 10, $2010 \quad$ (http://www.telquelonline.com/301/couverture_301.shtml).

Jedwab, Jack. 2006. "Religion, Ethnicity and Belonging to Canada: People of Muslim Faith as Attached to Canada as Other Canadians." Association for Canadian Studies. Retrieved June 13, 2006.

(www.fondationtrudeau.ca/.../resource/public/conferen/articles/second/jedwabre\&r0_1 =en\&r0_output=xml).

Korteweg, Anna C. 2006. "The Sharia Debate in Ontario.” ISIM Review 18: 50-51.

Lacroix, Thomas. 2005. Les réseaux marocains du développement: Géographie du transnational et politique du territorial. Paris: Presses de la Fondation Nationale des Sciences Politiques.

Leane, Geoffey W.G. 2011. "Rights of Ethnic Minorities in Liberal Democracies: Has France Gone Too Far in Banning Muslim Women from Wearing the Burqa?" Human Rights Quarterly 33 (4): 1032-1061.

Lessard, Annie. 2007. "Les Musulmans sont moins tolérants que les Québécois. Point de Bascule." Point de Bascule. La défense de nos libertés par l'éducation sur la menace de l'islamisme, December 20, 2007. Retrieved March 28, 2013 (http://www.pointdebasculecanada.ca/article/152-les-marocains-musulmans-sontmoins-tolerants-que-les-quebecois.php).

López García, Bernabé. 2012. "Le Maroc et le printemps arabe dans un monde en plein changement." Papers IEMed 11.

Maddy-Weitzman, Bruce and Daniel Zisenwine, eds. 2012. Contemporary Morocco. State, Politics and Society under Mohammed VI. London: Routledge.

Maghraoui, Driss. 2009. "The Strengths and Limits of Religious Reform in Morocco." Mediterranean Politics 14 (2): 195-211.

Mandaville, Peter G. 2001. Transnational Muslim Politics. Reimagining the Umma. London: Routledge.

2007. Global Political Islam. London: Routldge.

Marechaud, Cerise. 2007. "L'islam marocain dans toute sa complexité." La Croix, N 37936, (Décembre 24). Retrieved April 4, 2013

(https://groups.google.com/forum/?fromgroups=\#!topic/musulmans-duquebec/V9unhOhHy5Q).

Moon, Richard, ed. 2008. Law and Religious Pluralism in Canada. Vancouver: UBC Press.

Moore, Sally Falk. 1987. "Explaining the Present: theoretical dilemmas in processual ethnography." American Ethnologist 14 (4): 727-736. 
Point de Bascule. 2007. "Canada - Un musulman converti au christianisme persécuté par sa mère - il ne marchera plus jamais." Retrieved March 28, 2013 (http://pointdebasculecanada.ca/actualites/1000152.html).

Rachik, Hassan. 2003. Symboliser la nation. Essai sur l'usage des identités collectives au Maroc. Casablanca: Éditions Le Fennec.

Razack, Sherene H. 2007. The 'Sharia Law Debate' in Ontario: The Modernity/Premodernity Distinction in Legal Efforts to Protect Women from Culture." Feminist Legal Studies 15: 3-32.

Rohe, Matthias. 2011. "Alternative Dispute Resolution in Europe under the Auspices of Religious Norms.” RELIGARE Working Paper, N6. Retrieved March 27, 2013 (http://www.religareproject.eu/system/files/Alternative\%20Dispute\%20Resolution\%20 by\%20Rohe\%20e-version.pdf).

Roy, Olivier. 2004. Globalized Islam. The Search for a New Umma. London: Hurst.

Sabry, Tarik. 2005. "Emigration as Popular Culture." European Journal of Cultural Studies 8: 5-22.

Salih, Ruba. 2002. "Reformulating Tradition and Modernity: Moroccan Migrant Women and the Transnational Division of Ritual Space." Global Networks 2: 219-231.

Sater, James N. 2007. Civil Society and Political Change in Morocco. London: Routledge.

Sharify-Funk, Meena. 2010. "Muslims and the Politics of 'Reasonable Accommodation': Analyzing the Bouchard-Taylor Report and its Impact on the Canadian Province of Québec.” Journal of Muslim Minority Affairs 30 (4): 535-553.

Sharify-Funk, Meena. 2011. "Governing the Face Veil: Quebec's Bill 94 and the Transnational Politics of Women's Identity.” International Journal of Canadian Studies 43: 135-163.

Schlee, Günther. 2004. "Taking Sides and Constructing Identities." Journal of the Royal Anthropological Institute 10 (1): 135-156.

Snel, Eric, Godfried Engbersen and Arjen Leerkes. 2006. "Transnational Involvement and Social Integration." Global Networks 6: 285-308.

Storm, Lise. 2007. Democratization in Morocco. The Political Elite and Struggle for Power in the Post-independence State. London: Routledge.

Tierney, Stephen, ed. 2007. Multiculturalism and the Canadian Constitution. Vancouver: University of British Columbia Press.

Turner, Bertram. 2007. "Islamic Activism and Anti-Terrorism Legislation in Morocco." Max Planck Institute for Social Anthropology Working Papers № 91. Halle/Saale: Max Planck Institute for Social Anthropology.

van der Ven, Johannes A. 2011. "Separation of Church and State and Freedom of Religion: Left to the Gods? An Empirical Study among Dutch Young People.” Pp. 121-168 in The Public Significance of Religion, edited by Leslie J. Francis and Hans-Georg Ziebertz. Leiden: Brill.

Wilcox, Luke. 2009. "Reshaping Civil Society through a Truth Commission: Human Rights in Morocco's Process of Political Reform." The International Journal of Transitional Justice 3: 49-68.

Zeghal, Malika. 2005. Les islamistes marocains. Le défi à la monarchie. Casablanca: Le Fennec. 
Zillinger, Martin. 2009. "Rappen für Gott, König und Vaterland: Über Trance, Kulturalisierung und Macht in Marokko und der marokkanischen Migration." Pp. 135-176 in Wider den Kulturenzwang. Migration, Kulturalisierung, Weltliteratur, edited by Ökan Ezli, Dorothee Kimminich and Annette Werberger. Bielefeld: Transcript.

RECODE Online Working Paper No. 27

January 2014

ISSN 2242-3559 